\title{
Co-occurrence of type-A and type-B trichothecenes in barley from a northern region of Spain
}

\author{
María Ibáñez-Vea ${ }^{1}$, Elena Lizarraga ${ }^{1}$, Elena González-Peñas ${ }^{1 *}$, Adela López de Cerain ${ }^{2}$ \\ ${ }^{1}$ Department of Organic and Pharmaceutical Chemistry \\ ${ }^{2}$ Department of Nutrition, Food Sciences, Physiology and Toxicology \\ Faculty of Pharmacy, C.I.F.A., University of Navarra \\ Irunlarrea 1, 31008, Pamplona, Navarra, Spain
}

*Corresponding author: Elena González-Peñas PhD: Tel: +34 948425653. Fax: +34 948 425652. E-mail: mgpenas@unav.es

E-mail addresses of all coauthors: mivea@alumni.unav.es (María Ibáñez-Vea PhD); elizarraga@unav.es (Elena Lizarraga PhD); acerain@unav.es (Adela López de Cerain $\mathrm{PhD})$. 


\section{ABSTRACT}

In this survey, 123 barley samples from a northern region of Spain (Navarra) have been analyzed for co-occurrence of eight type-A and type-B trichothecenes (DON, NIV, 3-ADON, 15-ADON, FUS-X, T-2, HT-2 and DAS). Samples were classified according to place and year of harvest (2007 and 2008), type of farming (organic or traditional) and variety of barley. The rains during anthesis had a great influence on the trichothecene levels, observing higher contaminations in samples collected during 2008. In addition, type-A trichothecenes tend to be more present in cooler areas, while type-B appears more often in warmer regions. The type of farming has not led to significant differences in mycotoxins levels, although a trend towards higher incidence and contamination in traditional samples has been observed. On the other hand, it was observed that Pewter, the favorite barley variety for the malting industry in Spain, has been the most susceptible to contamination with trichothecenes.

\section{Keywords}

Trichothecenes, mycotoxins, organic farming, barley. 


\section{INTRODUCTION}

Fusarium head blight (FHB) is a fungal disease of wheat and other small grains caused by several species of the genus Fusarium that produce important economic loss throughout the entire world (Miller, 1994). The major species associated with FHB in Europe are F. graminearum, F. avenaceum and F. culmorum, and to a lesser extent, $F$. poae, F. cerealis, F. equiseti, F. sporotrichioides and F. tricinctum (Bottalico and Perrone, 2002). These fungi are widespread pathogens capable of producing mycotoxins, with trichothecenes being one of the most important families due to their toxicity and world-wide prevalence.

F. graminearum, common in moist-warm continental climates, and F. culmorum, more often found in maritime and cooler European areas, produce type-B trichothecenes such as deoxynivalenol (DON), nivalenol (NIV) and their acetylated derivatives (3-acetyldeoxynivalenol (3-ADON) and 15-acetyldeoxynivalenol (15-ADON), and fusarenon-X (FUS-X)). F. sporotrichioides and powdery F. poae are found in cooler European areas producing type-A trichothecenes ( $\mathrm{T}-2$ and HT-2 toxins, diacetoxyscirpenol (DAS)).

It is estimated that $25 \%$ of the world's crop production and $20 \%$ of crop production within the European Union may be contaminated with mycotoxins. Trichothecenes appear like natural contaminants in cereal grains such as wheat, barley, oat, maize, rice, and derived products such as bread, malt and beer (Pronk, Schothorst and van Egmond, 2002, EFSA, 2004).

Trichothecene levels can vary considerately depending on climatic, as well as on seasonal and geographic conditions, because the influence of several factors can lead to a change in the Fusarium profile (Bottalico and Perrone, 2002). Therefore, it is difficult 
to make generalizations with regard to trichothecene occurrence in cereals. It is wellknown that DON is widely prevalent in high concentrations. In naturally contaminated foodstuffs, DON is normally present together with its precursor (3-ADON and 15-ADON), and also with other Fusarium mycotoxins, mainly type-B trichothecenes and zearalenone (Josephs, Derbyshire, Stroka, Emons and Anklam, 2004). In European agricultural commodities, type-A trichothecenes occur less frequently and at lower concentrations than DON. Type-A trichothecenes have a higher toxicity than those of type-B (Rotter, Prelusky and Pestka, 1996).

The occurrence of trichothecenes in cereals is of great concern to animal and human health. The ingestion of trichothecene mold-contaminated cereal grains can initiate a wide range of effects on animals such as skin and gastrointestinal irritation or necrosis, hematological disorders, diarrhea, vomiting and feed refusal, decreased body weight gain, immunological alterations, and damage to the hematopoietic systems in bone narrow, spleen, thymus and lymph nodes (Pronk, Schothorst and van Egmond, 2002). At a cellular level, they are potent inhibitors of protein, DNA and RNA synthesis (Rotter, Prelusky and Pestka, 1996). With regard to human diseases, DON have been related to acute human toxicoses such as Akakabi-byo or red mold disease, reported in countries such as Russia, Japan and China. T-2 has been associated with the alimentary toxic aleukia (ATA) disease that took place in Russia during World War II (IARC, 1993).

Surveys have been carried out to study the presence of trichothecenes in barley from several countries (Pan, Bonsignore, Rivas, Perera and Bettucci, 2007, Biselli and Hummert, 2005, Campbell, Choo, Vigier and Underhill, 2002, Eskola, Parikka and Rizzo, 2001, Keblys, Flaoyen and Langseth, 2000, Langseth and Rundberget, 1999, Langseth and Elen, 1997), although, to the author's knowledge, there is no published 
data regarding trichothecene occurrence in barley from Spain, despite the fact that this country is one of the largest UE cereal producers. Moreover, in Spain, 52\% of the arable land was devoted to barley production in 2007, followed by wheat and corn. In the case of cereal grains, a survey carried out in Galicia (Spain) in the eighties described the presence of DON and ZEA in corn (Muñoz, Cardelle, Pereiro and Riguera, 1990).

Recent reports cite different methods for the determination of DON and NIV in cornbased food products from Spain (Castillo, Montes, Navarro, Segarra, Cuesta and Hernández, 2008), for the simultaneous analysis of five type-A and type-B trichothecenes in wheat flour (Sospedra, Blesa, Soriano and Manes, 2010), and for the quantification of DON, T-2 and HT-2 in cereal-based foods (Cano-Sancho et al., 2011). According to the first research, the incidence of DON and NIV in corn-based food products is lower than in similar foods analyzed in other EU countries.

Due to the high frequency of food and feed contamination with trichothecenes and the potential risk associated with them, the European Union has established harmonized regulations for DON in cereals and derived products, as well as official protocols for sampling and analysis. As a result, the EU has set a maximum permitted level of $1250 \mu \mathrm{g} \mathrm{kg}^{-1}$ for DON in unprocessed cereals (European Commission, 2006). In addition, the EU has stated the need for a reliable and sensitive method, more occurrence data, and more research regarding the factors involved in the presence of T-2 and HT-2 toxins in cereals and cereal products (European Commission, 2006). Permitted levels for T-2 and HT-2 toxins are currently under discussion.

Based on the aforementioned reasons, the objectives established for this work were:

a) To evaluate the presence of trichothecenes in barley samples from Navarra, a northern region of Spain. 
b) To study different factors that could affect the production and presence of trichothecenes: the influence of the year of harvest, place of the harvest, type of farming (organic or traditional) and variety of barley.

c) To analyze the possible relationship between the co-occurrence of different toxins.

\section{MATERIALS AND METHODS}

\subsection{Chemicals and reagents}

Trichothecene standards were purchased from Fluka (Schnelldorf, Germany) as certified reference materials and pentafluoropropionic anhydride (grade derivatization 99\%) from Aldrich (Schnelldorf, Germany). Acetonitrile HPLC grade, $\alpha$-chloralose, imidazole, sodium bicarbonate and sodium sulphate anhydrous were supplied by Sigma-Aldrich (St. Quentin Fallavier, France) and pro-analysis grade toluene by Panreac (Barcelona, Spain). Millipore type I water was obtained daily from a Milli-Q water-purifying system. Multisep ${ }^{\circledR} 227$ Trich+ columns were purchased from Romer Labs ${ }^{\circledR}$ (Tulln, Austria).

\subsection{Barley samples}

One hundred twenty-three barley samples were collected from the 2007 and 2008 harvests. Most of the samples were provided by national factories dedicated to the production of foodstuffs and feed after having applied their own sampling procedures for cereal quality control; other samples were collected from agricultural cooperatives. All samples are from Navarra, a northern region of Spain that is characterized by its climatic diversity, divided into seven zones (see figure 1). The climate in the northwestern area (referred to as the "Noroeste" area) is temperate maritime warm, with an annual rainfall of $1100-2500 \mathrm{~L} / \mathrm{m}^{2}$ and an average annual temperature of $8.5-$ 
$14.5^{\circ} \mathrm{C}$. The annual mean rainfall in the Pyrenees area ranges between 700 to $2200 \mathrm{~L} / \mathrm{m}^{2}$, and the mean temperature ranges between 7 and $15^{\circ} \mathrm{C}$. The central area of Navarra, formed by the zones of Pamplona, Tierra Estella and Navarra Media, is characterized by a Mediterranean climate (annual mean rainfall: $450-1100 \mathrm{~L} / \mathrm{m}^{2}$; annual mean temperature: $11-14^{\circ} \mathrm{C}$ ). The southern area (zones of Ribera Alta and Tudela) is the driest part of Navarra (annual mean rainfall lower than $500 \mathrm{~L} / \mathrm{m}^{2}$ ) and the average annual temperature is $14^{\circ} \mathrm{C}$. Due to the climatic conditions of the region, the moisture content of the samples was less than $15 \%$ upon arrival at the laboratory and the samples were then stored at $4^{\circ} \mathrm{C}$ until their analysis.

The samples were grouped according to the year and place of production, the type of farming and the variety of barley. Forty-eight samples were obtained from the 2007 harvest and 75 samples were obtained from the following year of harvest. Of the 123 samples, 25 came from the Tudela zone, 30 from Ribera Alta, 40 from Navarra Media, 21 from Tierra Estella, 2 from Pamplona and 5 from the Pyrenees zone (see figure 1). Eleven of these samples were obtained from organic farming carried out in the Tudela zone while the other one hundred twelve samples came from traditional farming. With regard to the variety of the cereal, more than a dozen barley varieties were collected; Hispanic, Pewter and Naturel were the most cultivated varieties during the 2007 and 2008 harvests in Navarra. Twenty-nine samples were from Hispanic variety, 37 from Pewter and 15 from Naturel.

\subsection{Standard solutions}

A stock standard solution containing $8 \mathrm{mg} \mathrm{L}^{-1}$ of DON, 3-ADON, 15-ADON, NIV, FUS-X, T-2, HT-2, NEO (neosolaniol) and DAS was prepared by diluting trichothecene commercial solution volumes in acetonitrile. Working standard solutions containing 0.8 or $0.2 \mathrm{mg} \mathrm{L}^{-1}$ of each one of the analytes were prepared by diluting appropriate volumes 
of the stock standard solution with acetonitrile. An internal standard solution of $300 \mu \mathrm{g} \mathrm{L}^{-1}$ was prepared by diluting $\alpha$-chloralose in acetonitrile. All of the solutions were stored at $-20^{\circ} \mathrm{C}$ and maintained at room temperature for 30 minutes before each use.

For calibration sample preparation, blank barley sample extracts were fortified with an appropriate amount of a multi-analyte working standard solution, and then the extract was subjected to the derivatization process just as the real samples had.

\subsection{Mycotoxin analysis}

The samples were analyzed according to a method previously validated in-house for the determination of eight type-A and type-B trichothecenes (DON, 3-ADON, 15-ADON, NIV, FUS-X, T-2, HT-2 and DAS) (Ibáñez-Vea, Lizarraga and González-Peñas, 2011). Briefly, the method consists of the extraction of 10 grams of milled sample with a mixture of acetonitrile-water (84:16) and the clean-up of $10 \mathrm{~mL}$ of the extract with Multisep $^{\circledR} 227$ Trich + column from Romer Labs ${ }^{\circledR}$. Six milliliters of the eluate were evaporated to dryness, and then derivatized with pentafluoropropionic anhydride (PFPA) and imidazole.

The derivatized extract was analyzed in a gas chromatographic system coupled to a quadrupole mass spectrometer and controlled by ChemStation software (Agilent Technologies). The analyses were developed in a HP-5MS capillary column, with electron impact detection in selected-ion monitoring (SIM) mode.

The method was validated in barley samples with matrix-matched calibration standards in the ranges $10-200 \mu \mathrm{g} \mathrm{kg}^{-1}$ and $200-2000 \mu \mathrm{g} \mathrm{kg}$, except for DON and HT-2, in which the ranges of $20-200 \mu \mathrm{g} \mathrm{kg}^{-1}$ and $200-2000 \mu \mathrm{g} \mathrm{kg}^{-1}$ were evaluated. The limit of detection ranged from 0.3 to $3.9 \mu \mathrm{g} \mathrm{kg}^{-1}$ and the limit of quantification from 10 to 
$20 \mu \mathrm{g} \mathrm{kg}^{-1}$. Recovery percentages (applied as correction factor in quantifying the samples) were between 92.0 and $101.9 \%$ for all the mycotoxins, except for NIV, which showed a lower recovery $(63.1 \%)$. In every case, the relative standard deviation was lower than $15 \%$. The method was valid for the trichothecene analysis and fulfilled the validation requirements established by the European Commission. Standard solutions of the eight trichothecenes studied were analyzed before and after each sample analysis sequence in order to verify that the method met the established validation criteria.

\subsection{Statistical analysis}

Statistical analysis of the data was performed using the SPSS program 15.0. The study has taken into account the trichotecene levels between the LOD and LOQ; in the case of a value lower than the LOD, half of the LOD value was used. This makes mandatory the use of non parametric statistical methods.

The homogeneity of the variance was evaluated by the Levene's test. Depending upon the significance of these preliminary tests, the levels of the samples were analysed by the non-parametric Mann-Whitney U test or Median test for two independent samples, and Kruskal-Wallis test or Median test for $\mathrm{k}$ independent samples. The incidence of the toxins was analyzed using the contingency test. A probability value of 0.05 was used to determine the statistical significance.

Correlation between the levels of two toxins has been verified with Spearman's Rank Correlation test, due to the lack of univariate and bivariate normality. The statistical significance was determined using a probability value of 0.01 . 


\section{RESULTS}

A summary of the results obtained in this survey is shown in table 1. Ninety-seven percent of the samples had detectable levels of one or more mycotoxins. Ninety-five percent of the samples were contaminated with DON, although none of them exceeded the maximum permitted limit by legislation $\left(1250 \mu \mathrm{g} \mathrm{kg}^{-1}\right)$, with $1111.3 \mu \mathrm{g} \mathrm{kg}^{-1}$ being the maximum level found (see table 1). Only one sample presented a value higher than $1000 \mu \mathrm{g} \mathrm{kg}^{-1}$ and $7 \%$ of the samples contained $100 \mu \mathrm{g} \mathrm{kg}^{-1}$ or more. On the other hand, NIV had a lower occurrence rate, with only $20 \%$ of the samples presenting this mycotoxin, and FUS-X was only detected in two samples. Type-A trichothecenes were also present: DAS at low concentrations in $25 \%$ of the samples, and T-2 and HT-2 were found in 10 and $24 \%$ of the samples, respectively. T-2 always appeared together with HT-2, and generally, at a lower concentration. Only one sample presented a concentration higher than $100 \mu \mathrm{g} \mathrm{kg}^{-1}$ for the sum of T-2 and HT-2 (532.5 $\left.\mu \mathrm{g} \mathrm{kg}^{-1}\right)$.

Results have shown that a great number of samples were contaminated with several Fusarium toxins. Sixty-seven percent of the samples were co-contaminated with two or more mycotoxins, and $43 \%$ were contaminated with three or more. Fifty-nine percent of the samples were contaminated simultaneously with DON and its precursors (15-ADON and/or 3-ADON) and 22\% presented a combination of DON and HT-2 or DON and T-2 + HT-2. DON was found together with their precursors 15-ADON (57\%) and 3-ADON (28\%). 3-ADON was always present together with 15-ADON, although at a lower concentration. In fact, a very elevated positive correlation (Cohen classification) has been observed between the concentration of DON and 15-ADON $\left(r_{s}=0.758\right)$ and 3-ADON $\left(r_{s}=0.723\right)$. Other correlations found were as follows: great correlation between 15-ADON and 3-ADON $\left(r_{\mathrm{s}}=0.551\right)$, and between T-2 and HT-2 ( $\left.\mathrm{r}_{\mathrm{s}}=0.659\right)$;

medium correlation between DON and DAS $\left(\mathrm{r}_{\mathrm{s}}=0.440\right), 15-\mathrm{ADON}$ and NIV 
$\left(r_{\mathrm{s}}=0.450\right), 15-\mathrm{ADON}$ and DAS $\left(\mathrm{r}_{\mathrm{s}}=0.452\right), \mathrm{NIV}$ and DAS $\left(\mathrm{r}_{\mathrm{s}}=0.475\right), \mathrm{NIV}$ and HT-2 $\left(r_{\mathrm{s}}=0.375\right)$, NIV and T-2 $\left(\mathrm{r}_{\mathrm{s}}=0.310\right)$, DAS and HT-2 $\left(\mathrm{r}_{\mathrm{s}}=0.491\right)$, and DAS and T-2 $\left(r_{\mathrm{s}}=0.305\right)$; and low correlation between DON and NIV $\left(r_{\mathrm{s}}=0.290\right), 3-\mathrm{ADON}$ and $\operatorname{DAS}\left(\mathrm{r}_{\mathrm{s}}=0.274\right)$ and $3-\mathrm{ADON}$ and NIV $\left(\mathrm{r}_{\mathrm{s}}=0.256\right)$.

Some researches have affirmed that non-acetylated forms predominate over the acetylated forms (DON $>3$ and 15-ADON, NIV $>$ FUS-X), except for T-2 (T-2 > HT-2) (Langseth and Rundberget, 1999). In the analyzed samples, DON and NIV were present in higher concentrations than 15-ADON and 3-ADON, and FUS-X, respectively, but in the case of T-2 and HT-2, HT-2 is present at a higher concentration and incidence than $\mathrm{T}-2$.

To check the influence of the climatologic conditions over the trichothecene levels, the samples of traditional farming were divided according to the year of harvest (2007 and 2008). In general, a higher incidence and higher levels of trichothecenes were observed in the samples cultivated during the 2008 harvest (see table 2). The mean values of the positive samples in the 2007 harvest were less than the limits of quantification of each mycotoxin. The nonparametric statistical studies (Mann-Whitney U test or Median test for two independent samples) have shown that significant differences exist between the results found for the two harvests for DON, NIV, 3-ADON, 15-ADON and DAS (see table 2). The FUS-X, T-2 and HT-2 mean values of both harvests were not significant, although a greater trend towards contamination was observed in the samples collected during the 2008 harvest.

In this survey, the climatologic influence has also been evaluated, classifying the traditional samples according to their geographical origin. The samples collected from the 2007 harvest did not show any toxin distribution based on origin (results not shown). However, the results of the samples from 2008 showed that the region with the 
highest levels of type-A trichothecenes was Tierra Estella; and the highest levels of type-B were found in Tudela and Ribera Alta (see table 3). Yet, in Navarra Media, the level found for NIV was the highest of all the zones studied. Despite all of the aforementioned, the statistical study did not show significant differences between the different regions, except for HT-2 which presented differences between Tierra Estella and the rest of the regions, and for DAS, which showed significant differences in the incidence percentages, with the highest percentage being obtained in Tierra Estella (see table 3).

Major barley varieties grown in Navarra in 2007 and 2008 were Hispanic, Naturel and Pewter. The results found for the traditional samples showed that Hispanic presented the lowest prevalence (see table 4). Pewter, presented a higher incidence and contamination with trichothecenes. The statistical study (Kruskal-Wallis test and contingency test) proved that significant differences among levels obtained from the three varieties under study exist for DON, NIV, 15-ADON, DAS and HT-2 and that there are also significant differences among the incidence of the samples in the three varieties for NIV, 15ADON, DAS, T-2 and HT-2 (see table 4).

The samples were also classified according to the type of farming, traditional or organic. When comparing the conventional and organic samples collected in Tudela, an occurrence of $100 \%$ was observed for DON in both types of samples, although a higher contamination level was found in the traditional samples (see table 5). Mycotoxins, 15ADON and 3-ADON showed higher incidence and higher contamination rates in the samples from traditional farming. On the other hand, detectable levels of NIV, FUS-X, HT-2 and T-2 were not found in the organic samples analyzed, and in the conventional samples, only one sample presented levels above the limits of detection for HT-2 and T- 
2 (see table 5). Despite all of this, Contingency tests did not show significant differences between the traditional and organic samples from Tudela.

\section{DISCUSSION}

In this survey, 123 barley samples from different regions of Navarra have been analyzed in order to assess the co-occurrence of eight types A and B trichothecenes in this region from Spain. From a general point of view, the trichothecene levels present in barley were less than in barley from other European countries, although the percentage of positive samples was higher (Langseth and Elen, 1997, Müller, Reimann, Schumacher and Schwadorf, 1997, Garaleviciene, Pettersson, Elwinger, Lindberg and Augonyte, 2001). The trichothecene contamination rates reported for barley from 12 European countries in the SCOOP (2003) report were 47, 8, 4, 3 and 5\% for DON, NIV, 3ADON, T-2 and HT-2, respectively, with 37 and $15 \mu \mathrm{g} \mathrm{kg}^{-1}$ being the DON and NIV mean concentration values, respectively (Gareis et al., 2003). In this study, 95, 20, 28, 10 and $24 \%$ of the samples were contaminated with these toxins, respectively, with a mean level of 57 and $5 \mu \mathrm{g} \mathrm{kg}^{-1}$ for DON and NIV. This finding can be attributed to the higher sensitivity of our method because the SCOOP data available was obtained with analytical methods having high LOD (up to $100 \mu \mathrm{g} \mathrm{kg}^{-1}$ ).

In surveys on barley from Norway, Germany, UK, Canada and Uruguay, several samples were contaminated with DON concentrations exceeding $1000 \mu \mathrm{g} \mathrm{kg}^{-1}$ (Pan, Bonsignore, Rivas, Perera and Bettucci, 2007, Campbell, Choo, Vigier and Underhill, 2002, Langseth and Elen, 1997, Müller, Reimann, Schumacher and Schwadorf, 1997, Edwards, 2009a). However, in our study, this only occurs in one sample $\left(1111.3 \mu \mathrm{g} \mathrm{kg}^{-1}\right.$ of DON) and in Lithuania, $93-100 \%$ of the samples studied were contaminated with

low levels, ranging from traces to $372 \mu \mathrm{g} \mathrm{kg}^{-1}$ (Mankeviciene, Butkuté, Dabkevicius and 
Suproniene, 2007). On the other hand, the NIV levels observed were lower than the DON levels; this coincides with that found by other researches, who state that this toxin appears to be less important than DON in European cereals (Bernhoft, Clasen, Kristoffersen and Torp, 2010).

With regard to T-2 and HT-2 values, studies from northern Europe showed higher mean concentrations in barley samples. In Norway, $22 \%$ and $5 \%$ of barley samples were positive for HT-2 and T-2, with a mean concentration in positive samples of 73 and $85 \mu \mathrm{g} \mathrm{kg}^{-1}$ (Langseth and Rundberget, 1999). During a period of five years, in a southwestern area of Germany, the incidence of these toxins varied between 0 and $9 \%$ and 2 and $29 \%$, respectively, with mean contents at $8-288$ and $2-305 \mu \mathrm{gg}^{-1}$, respectively (Müller, Reimann, Schumacher and Schwadorf, 1997). A high incidence for HT-2 and T-2 (34\% and 14\%) was found in barley samples from Lithuania, with a mean concentration in the positive samples of 41 and $40 \mu \mathrm{g} \mathrm{kg}^{-1}$, respectively (Keblys, Flaoyen and Langseth, 2000). In the UK, HT-2 and T-2 were detected in 36 and $12 \%$ of the samples, with mean concentrations less than or equal to $10 \mu \mathrm{gg}^{-1}$ (Edwards, 2009a). However, the HT-2 and T-2 mean levels found in our study were 4.3 and $3.9 \mu \mathrm{g} \mathrm{kg}^{-1}$ and the mean values of the positive samples were 14.8 and $34.9 \mu \mathrm{g} \mathrm{kg}^{-1}$, respectively. These results coincide with some researches who state that wheat and barley crops grown in southern European areas appear to be less contaminated by Fusarium toxins than in the northern areas (Bottalico and Perrone, 2002).

Deoxynivalenol, which is produced by F. graminearum and F. culmorum, presented a positive correlation with its precursors (15-ADON and/or 3-ADON), with more than half of the samples being contaminated with a combination of either two or three of these compounds. However, a low correlation between DON and NIV has been found despite having been produced by the same species. This finding suggests that the grains 
are less susceptible to the invasion of the chemotype producers of NIV, and that DON and NIV are not co-contaminants. There is no relationship between DON and T-2 and HT-2, although $21 \%$ of the samples presented a combination of DON and HT-2 or DON and T-2 + HT-2. These results coincide with those found in Poland by Perkowski, Kiecana and Kaczmarek (2003) . On the other hand, two thirds of the samples analyzed were contaminated with more than one mycotoxin, and almost half of them were contaminated with three or more toxins. From a toxicological point of view, the occurrence of several toxins from a same family may have additive effects (Speijers and Speijers, 2004). However, in the case of the combined incidence of DON and T-2, the effects observed in vitro appear to be antagonist (SCF, 2002). When assessing the risk or when designing toxicity studies, one should take into account the fact that there is a high likelihood of having several toxins in the same sample.

Miller et al. (1991) affirmed that DON is produced from 3-ADON by chemotypes IA in Europe and Asia (warmer regions) and from 15-ADON, by chemotypes IB, in USA and South America (cooler regions) (Miller, Grennhalgh, Wang and Lu, 1991). However, in our study, DON has been found together with their precursors, 3-ADON and 15-ADON. The results suggest that both chemotypes have been present in Navarra, Spain. The higher level of 15-ADON with respect to 3-ADON may be due to a smaller transformation of this toxin into its parent toxin or to a smaller production of DON by its chemotype IA as a result of climatologic conditions, among other factors. The presence of DON together with 3-ADON and 15-ADON in barley has also been found by other authors in Europe (Müller, Reimann, Schumacher and Schwadorf, 1997, Edwards, 2009a), although on some occasions only 3-ADON has been detected (Keblys, Flaoyen and Langseth, 2000). 
According to several researchers, the trichothecene levels appear to be conditioned by climate (Keblys, Flaoyen and Langseth, 2000, Langseth and Rundberget, 1999, Langseth and Elen, 1997, Müller, Reimann, Schumacher and Schwadorf, 1997, Mankeviciene, Butkuté, Dabkevicius and Suproniene, 2007). The incidence of Fusarium head blight (FHB) is directly related to the contamination of wheat and barley with DON (EFSA, 2004). The humidity, during and after anthesis, and the duration of rainfall, could be the main factors causing the emergence of FHB in the crops. In this survey, it has been observed that although 2007 was the wettest year for the past 55 years, between February and May, the rainfall did not concentrate during the flowering period of crops (May). Yet, in 2008, the rains during May could have led to the emergence of weeds and diseases such as septoria and fusaria, which caused significant yield loss. The accumulated precipitation during May 2007 was on the order of the mean annual precipitation while the accumulated rainfall during May 2008 was more than twice the average. This has resulted in a higher incidence and in higher trichothecene levels in the samples cultivated during 2008 harvest.

In addition, the influence of climatic conditions has also been observed in the differences found among the trichothecene contamination rates in the different regions. A greater presence of type-A trichothecenes has been found in samples grown in the Tierra Estella zone, where the mean annual rainfall is between 600 and $800 \mathrm{~mm}$. Yet most type-B trichothecenes occurred in the regions of Tudela and Ribera Alta, where the mean annual rainfall is less (Ribera Alta: between 400 and $500 \mathrm{~mm}$; Tudela: $<400 \mathrm{~mm}$ ) and the mean annual temperature is two degrees higher. With regard to these results, the climatologic conditions that characterize the Tierra Estella zone might be more favorable for the infection of crops with F. sporotrichioides and powdery F. poae, the main species which are responsible for the type-A trichothecene production. The 
warm climate, characteristic of the regions of Tudela and Ribera Alta, might favor the infection with F. graminearum.

Few surveys have checked the influence of the variety of barley on the production of mycotoxins in Europe (Edwards, 2007). This study has demonstrated that Pewter, the favorite variety of the Spanish malting industry, is probably the most susceptible to contamination with trichothecenes among the varieties that were studied. In addition, Hispanic presented higher resistance to FHB. Several researches have reported that trichothecenes and other toxins present in contaminated grains (barley and wheat) can survive the brewing process and therefore, reach humans through the food chain (Scott, 1996, Molto, Samar, Resnik, Martinez and Pacin, 2000). It is important to highlight the need for safe and reliable analytical methods for the determination of trichothecenes in barley and other foodstuffs, such as malt and beer.

There is a discussion about the relationship between agriculture practices and mycotoxin contamination. Several researches have presented higher trichothecene occurrence in traditional samples (Bernhoft, Clasen, Kristoffersen and Torp, 2010, Gottschalk, Barthel, Engelhardt, Bauer and Meyer, 2007, Edwards, 2009b), while others have shown higher contamination rates in organic samples (Malmauret, Parent-Massin, Hardy and Verger, 2002). In our case, despite the low number of organic samples that may have limited the results that were obtained, a higher incidence as well as higher contamination levels were observed in the conventional samples.

Another research found that there was no significant difference in the mycotoxin content of organic and traditional barley samples (Edwards, 2009a).

The European Scientific Committee on Food (SCF) evaluated Fusarium toxins such as DON, NIV, T-2 and HT-2, and established a tolerable daily intake (TDI) of $1 \mu \mathrm{g} \mathrm{kg}^{-1}$ b.w. per day for DON (SCF, 2002), which is in line with the temporary tolerable daily 
intake established by the Nordic Working Group (Eriksen and Alexander, 1998), and the provisional maximum tolerable daily intake (PMTDI) set by the Joint Expert Committee on Food Additives (JECFA) (JECFA, 2001). The SCF also established a temporary TDI (t-TDI) of 0.7 and $0.06 \mu \mathrm{g} \mathrm{kg}^{-1}$ b.w. per day for NIV and for the sum of T-2 and HT-2, respectively (SCF, 2002). The mean consumption of cereals in Spain is $239 \mathrm{~g} \mathrm{day}^{-1}$. Taking into account the mean values found for DON, NIV, T-2+HT-2 in this survey, it is evident that they are below the established TDI and t-TDI (see table 1). Yet, the maximum levels found for these compounds exceeded the TDI and t-TDI in all cases, except for NIV (see table 1). In any case, the ingest values found in our study are overestimated because the mean daily consumption of $239 \mathrm{~g}$ includes other cereals besides barley.

\section{CONCLUSIONS}

The analysis of 123 barley samples from Navarra has demonstrated the co-occurrence of type-A and type-B trichothecenes in this type of matrix, due to the fact that $77 \%$ of the samples were contaminated with two or more mycotoxins. In all of the samples, the maximum levels found for the different mycotoxins have been far below the maximum permitted levels established by the EU.

The rainfall during anthesis had a great influence on the trichothecene levels, observing higher contaminations in samples collected during 2008. In addition, type-A trichothecenes tend to appear more often in cooler areas, while type-B trichothecenes appear more often in warmer regions. The two types of farming have not led to significant differences in mycotoxin levels, although a trend towards higher incidence and higher contamination in traditional samples has been observed. In addition, it has 
been observed that Pewter, the favorite barley variety for the malting industry in Spain, has been the most susceptible to contamination with trichothecenes.

The calculated daily intake values which were obtained by using the mean levels of mycotoxins are low and the risk for the consumers can be considered to be very low also. However, the co-occurrence of several mycotoxins, and therefore synergic or additive effects, should be taking into account when determining permitted levels or risk assessment.

\section{ACKNOWLEDGEMENTS}

The authors are grateful to the personnel at the participating local grain delivery sites for their cooperation. We wish to extend our gratitude to Ms. Laura Stokes for reviewing the English version of this manuscript and to Dr. García-Granero for reviewing the statistical studies. We thank the Project of Research of University of Navarra (PIUNA Projects) and CAN (Caja Navarra; "Proyectos Tú eliges, tú decides") for the financial support received.

\section{BIBLIOGRAPHY}

Bernhoft, A., P. -. Clasen, A. B. Kristoffersen, \& M. Torp (2010). Less Fusarium infestation and mycotoxin contamination in organic than in conventional cereals. Food Additives and Contaminants, 27(6), 842-852.

Biselli, S., \& C. Hummert (2005). Development of a multicomponent method for Fusarium toxins using LC-MS/MS and its application during a survey for the content of T-2 toxin and deoxynivalenol in various feed and food samples. Food additives and contaminants, 22(8), 752-760. 
Bottalico, A., \& G. Perrone (2002). Toxigenic Fusarium species and mycotoxins associated with head blight in small-grain cereals in Europe. European Journal of Plant Pathology, 108 611-624.

Campbell, H., T. Choo, B. Vigier, \& L. Underhill (2002). Comparison of mycotoxin profiles among cereal samples from eastern Canada. Canadian Journal of Botany, $80(5), 526-532$.

Cano-Sancho, G., F. M. Valle-Algarra, M. Jiménez, P. Burdaspal, T. M. Legarda, A. J. Ramos, V. Sanchis, \& S. Marín (2011). Presence of trichothecenes and co-occurrence in cereal-based food from Catalonia (Spain). Food Control, 22(3-4), 490-495.

Castillo, M. A., R. Montes, A. Navarro, R. Segarra, G. Cuesta, \& E. Hernández (2008). Occurrence of deoxynivalenol and nivalenol in Spanish corn-based food products. Journal of Food Composition and Analysis, 21 423-427.

Edwards, G. (2009a). Fusarium mycotoxin content of UK organic and conventional barley. Food Additives Contaminants: Part A: Chemistry, Analysis, Control, Exposure Risk Assessment, 26(8), 1185-1190.

Edwards, G. (2009b). Fusarium mycotoxin content of UK organic and conventional oats. Food Additives Contaminants: Part A: Chemistry, Analysis, Control, Exposure Risk Assessment, 26(7), 1063-1069.

Edwards, S. (2007). Investigation of Fusarium mycotoxins in UK barley and oat production. Project Report No. 415 72-72.

Eriksen, G. S., \& Alexander, J. (1998). Fusarium toxins in cereals- a risk assessment, In Anonymous (pp. 7-58). Copenhagen, Denmark: Nordic Council of Ministers.

Eskola, M., P. Parikka, \& A. Rizzo (2001). Trichothecenes, ochratoxin A and zearalenone contamination and Fusarium infection in Finnish cereal samples in 1998. Food Additives and Contaminants, 18(8), 707-718. 
European Commission (2006). Commission regulation (EC) No 1881/2006 of 19 December 2006 setting maximum levels for certain contaminants in foodstuffs. Official Journal of the European Union, L 364 5-24.

EFSA (2004). Opinion of the Scientific Panel on Contaminants in the food chain on a request from the Commission related to deoxynivalenol (DON) as undesirable substance in animal feed. The EFSA Journal, 73 1-42.

Garaleviciene, D., H. Pettersson, K. Elwinger, J. E. Lindberg, \& G. Augonyte (2001). Effects of mould and toxin contaminated barley on laying hens performance and health. Archiv fur Tierernährung, 55(1),.

Gareis, M., R. C. Schothorst, A. Vidnes, C. Bergsten, B. Paulsen, C. Brera, \& M. Miraglia (2003). Task 3.2.10. Collection of Occurrence Data of Fusarium Toxins in Food and Assessment of Dietary Intake by the Population of EU Member States. SCOOP.

Gottschalk, C., J. Barthel, G. Engelhardt, J. Bauer, \& K. Meyer (2007). Occurrence of type A trichothecenes in conventionally and organically produced oats and oat products. Molecular Nutrition and Food Research, 511547.

IARC (1993). Working Group on the Evaluation of Carcinogenic Risks to Humans; Some Naturally Occurring Substances: Food Items and Constituents, Heterocyclic Aromatic Amines and Mycotoxins. Monographs on the Evaluation of Carcinogenic Risks to Humans, 56.

Ibáñez-Vea, M., E. Lizarraga, \& E. González-Peñas (2011). Simultaneous determination of type-A and type-B trichothecenes in barley samples by GC-MS. Food Control, 22 $1428-1434$

JECFA (2001). Safety evaluation of certain mycotoxins in food. Prepared by the Fiftysixth meeting of the Joint FAO/WHO Expert Committee on Food Additives. 47. 
Josephs, R. D., M. Derbyshire, J. Stroka, H. Emons, \& E. Anklam (2004). Trichothecenes: reference materials and method validation. Toxicological Letters, 153 123-132.

Keblys, M., A. Flaoyen, \& W. Langseth (2000). The occurrence of type A and B trichothecenes in Lithuanian cereals. Acta agriculturce Scandinavica. Section B, Soil and plant science, 50 155-160.

Langseth, W., \& O. Elen (1997). The occurrence of deoxynivalenol in Norwegian cereals - Differences between years and districts, 1988-1996. Acta agriculturce Scandinavica. Section B, Soil and plant science, 47(3), 176.

Langseth, W., \& T. Rundberget (1999). The occurrence of HT-2 toxin and other trichothecenes in Norwegian cereals. Mycopathologia, 147 157-165.

Malmauret, L., D. Parent-Massin, J. -. Hardy, \& P. Verger (2002). Contaminants in organic and conventional foodstuffs in France. Food Additives and Contaminants, 19(6), 524-532.

Mankeviciene, A., B. Butkuté, Z. Dabkevicius, \& S. Suproniene (2007). Fusarium mycotoxins in Lithuanian cereals from the 2004-2005 harvests. Annals of Agricultural and Environmental Medicine, 14 103-107.

Miller, J. D. (1994). Epidemiology of Fusarium Ear diseases of cereals, In Miller, J. D., \& Trenholm, H. L., Mycotoxins in grain. Compounds other than aflatoxin (pp. 19-36). Minnesota, USA: Eagan Press.

Miller, J. D., R. Grennhalgh, Y. Z. Wang, \& M. Lu (1991). Trichothecene chemotypes of 3 Fusarium species. Mycologia, 83(2), 121-130.

Molto, G., M. Samar, S. Resnik, E. Martinez, \& A. Pacin (2000). Occurrence of trichothecenes in Argentinean beer: a preliminary exposure assessment. Food additives and contaminants, 17(9), 809-813. 
Müller, H. M., J. Reimann, U. Schumacher, \& K. Schwadorf (1997). Natural occurrence of Fusarium toxins in barley harvested during five years in an area of southwest Germany. Mycopathologia, 137 185-192.

Muñoz, L., M. Cardelle, M. Pereiro, \& R. Riguera (1990). Occurrence of corn mycotoxins in Galicia (Northwest Spain). Journal of agricultural and food chemistry, 38 1004-1006.

Pan, D., F. Bonsignore, F. Rivas, G. Perera, \& L. Bettucci (2007). Deoxynivalenol in barley samples from Uruguay. International Journal of Food Microbiology, 114 149152.

Perkowski, J., I. Kiecana, \& Z. Kaczmarek (2003). Natural occurrence and distribution of Fusarium toxins in contaminated barley cultivars. European Journal of Plant Pathology, 109 331-339.

Pronk, M. E. J., R. C. Schothorst, \& H. P. van Egmond (2002). Toxicology and occurrence of nivalenol, fusarenon X, diacetoxyscirpenol, neosolaniol and 3- and 15acetyldeoxynivalenol: a review of six trichothecenes. RIVM, (Report 388802024/2002),. Rotter, B. A., D. B. Prelusky, \& J. J. Pestka (1996). Toxicology of deoxynivalenol (vomitoxin). Journal of Toxicology and Envoronmental Health, 48 1-34.

SCF (2002). Opinion of the Scientific Committee on Food on Fusarium toxins. Part 6: Group evaluation of T-2 toxin, HT-2 toxin, nivalenol and deoxynivalenol. 12.

Scott, P. M. (1996). Mycotoxins transmitted into beer from contaminated grains during brewing. Journal of AOAC International, 79 875-882.

Sospedra, I., J. Blesa, J. M. Soriano, \& J. Manes (2010). Use of the modified quick easy cheap effective rugged and safe sample preparation approach for the simultaneous analysis of type A- and B-trichothecenes in wheat flour. Journal of Chromatography A, $12171437-1440$ 
Speijers, G. J. A., \& M. H. M. Speijers (2004). Combined toxic effects of mycotoxins.

Toxicology letters, 153 91-98. 


\section{Figure captions}

Figure 1. Geographic regions from Navarra (based on “Zonificación 2000”). 


\section{FIGURES}

\section{Figure 1}

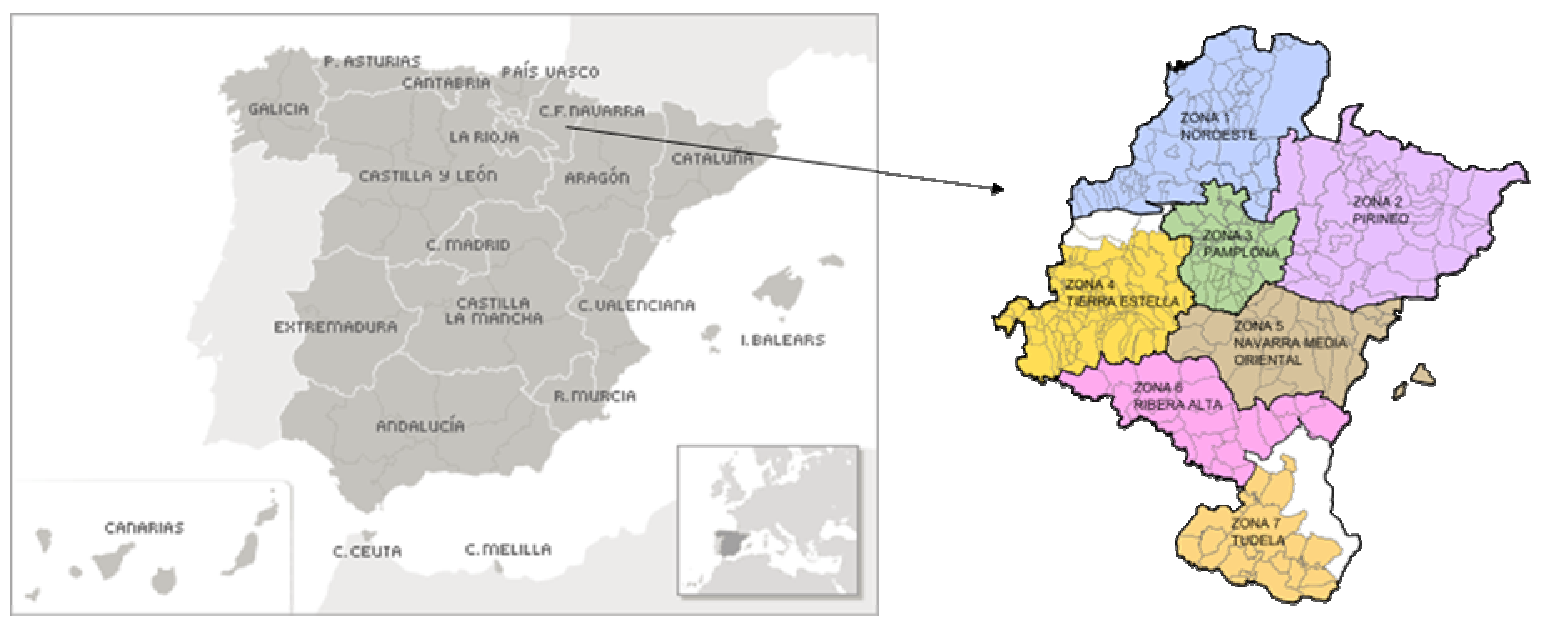

"Noroeste" = "Northwest"; "Pirineo" = "Pyrenees" 


\section{TABLES}

Table 1. Summary of mycotoxin levels found in barley samples.

\begin{tabular}{|c|c|c|c|c|c|c|c|c|c|c|}
\hline \multicolumn{2}{|l|}{ Parameter } & DON & NIV & FUS-X & $15-\mathrm{ADON}$ & 3-ADON & DAS & HT-2 & $\mathrm{T}-2$ & $\mathrm{~T}-2+\mathrm{HT}-2$ \\
\hline \multicolumn{2}{|c|}{$\%$ positive samples } & 95 & 20 & 2 & 57 & 28 & 25 & 24 & 10 & 24 \\
\hline \multicolumn{2}{|c|}{ Mean value of positive samples $\left(\mu \mathrm{g} \mathrm{kg}^{-1}\right)$} & 59.6 & 20.8 & 10.5 & 6.2 & 3.1 & 0.9 & 14.8 & 34.9 & 29.2 \\
\hline \multicolumn{2}{|c|}{ Mean value $\left(\mu \mathrm{g} \mathrm{kg}^{-1}\right)$} & 56.8 & 5.0 & 0.7 & 3.7 & 1.2 & 0.4 & 4.3 & 3.9 & 7.5 \\
\hline \multicolumn{2}{|c|}{ Median value $\left(\mu \mathrm{g} \mathrm{kg}^{-1}\right)$} & 21.4 & 0.7 & 0.6 & 2.1 & 0.3 & 0.3 & 0.6 & 0.2 & 0.7 \\
\hline \multicolumn{2}{|c|}{ Maximum level found $\left(\mu \mathrm{g} \mathrm{kg}^{-1}\right)$} & 1111.3 & 142.5 & 17.4 & 64.8 & 20.1 & 1.7 & 200.5 & 332.0 & 532.5 \\
\hline \multirow{2}{*}{ Daily intake $\left(\mu \mathrm{g} \mathrm{kg}^{-1} \text { w.b. }\right)^{*}$} & Mean & 0.2 & 0.0 & --- & --- & --- & --- & --- & --- & 0.0 \\
\hline & Maximum & 3.8 & 0.5 & --- & --- & --- & --- & --- & --- & 1.8 \\
\hline \multirow{2}{*}{$\%$ TDI } & Mean & 19.4 & 2.2 & --- & --- & --- & --- & --- & --- & 36.5 \\
\hline & Maximum & 379.4 & 69.5 & --- & --- & --- & --- & --- & --- & 2597.3 \\
\hline
\end{tabular}

* Body weight of $70 \mathrm{~kg}$. 
Table 2. Summary of mycotoxin levels found in traditional barley samples according to the year of harvest.

\begin{tabular}{|c|c|c|c|c|c|c|c|c|c|c|}
\hline Year of harvest & Parameter & DON & NIV & FUS-X & $15-\mathrm{ADON}$ & 3-ADON & DAS & HT-2 & $\mathrm{T}-2$ & $\mathrm{~T}-2+\mathrm{HT}-2$ \\
\hline \multirow{5}{*}{$2007(\mathrm{n}=44)$} & $\%$ positive samples & 88.6 & 9.1 & 2.3 & 20.5 & 13.6 & 4.5 & 22.7 & 11.4 & 22.7 \\
\hline & $\begin{array}{l}\text { Mean value of positive samples } \\
\qquad\left(\mu \mathrm{g} \mathrm{kg}^{-1}\right)\end{array}$ & 21.7 & 7.4 & 17.4 & 2.4 & 1.0 & 0.9 & 7.8 & 9.2 & 12.4 \\
\hline & Mean value $\left(\mu \mathrm{g} \mathrm{kg}^{-1}\right)$ & 19.5 & 1.1 & 1.0 & 0.6 & 0.4 & 0.3 & 2.2 & 1.2 & 3.4 \\
\hline & Median value $\left(\mu \mathrm{g} \mathrm{kg}^{-1}\right)$ & 11.5 & 0.7 & 0.6 & 0.2 & 0.3 & 0.3 & 0.6 & 0.2 & 0.7 \\
\hline & Maximum level found $\left(\mu \mathrm{g} \mathrm{kg}^{-1}\right)$ & 119.9 & 12.5 & 17.4 & 3.5 & 1.7 & 1.1 & 16.4 & 22.6 & 38.8 \\
\hline \multirow{5}{*}{$2008(\mathrm{n}=68)$} & $\%$ positive samples & 98.5 & 30.9 & 1.5 & 80.9 & 64.7 & 42.6 & 30.9 & 10.3 & 30.9 \\
\hline & $\begin{array}{l}\text { Mean value of positive samples } \\
\qquad\left(\mu \mathrm{g} \mathrm{kg}^{-1}\right)\end{array}$ & 86.2 & 22.7 & 3.6 & 7.2 & 3.7 & 0.9 & 18.5 & 53.2 & 38.1 \\
\hline & Mean value $\left(\mu \mathrm{g} \mathrm{kg}^{-1}\right)$ & 85.0 & 7.5 & 0.6 & 5.8 & 1.5 & 0.5 & 5.6 & 5.6 & 11.2 \\
\hline & Median value $\left(\mu \mathrm{g} \mathrm{kg}^{-1}\right)$ & 31.0 & 0.7 & 0.6 & 2.6 & 0.3 & 0.3 & 0.6 & 0.2 & 0.7 \\
\hline & Maximum level found $\left(\mu \mathrm{g} \mathrm{kg}^{-1}\right)$ & 1111.3 & 142.5 & 3.6 & 64.8 & 20.1 & 1.7 & 200.5 & 332.0 & 532.5 \\
\hline \multirow{2}{*}{ Mann-Whitney U Test } & Statistic & 731.500 & $9.188^{*}$ & 1483.500 & $33.690^{*}$ & $6.390^{*}$ & $18.279^{*}$ & 1418.000 & 1483.500 & --- \\
\hline & Significance & $<0.001$ & 0.002 & 0.745 & $<0.001$ & 0.011 & $<0.001$ & 0.546 & 0.890 & --- \\
\hline \multirow{2}{*}{ Contingency Test } & Statistic & 3.390 & 9.188 & 0.098 & 39.832 & 6.390 & 18.279 & 0.378 & 0.000 & --- \\
\hline & Significance & 0.066 & 0.002 & 1.000 & $<0.001$ & 0.011 & $<0.001$ & 0.538 & 1.000 & --- \\
\hline
\end{tabular}

* Median Test 
Table 3. Summary of mycotoxin levels found in barley according to the origin of the samples.

\begin{tabular}{|c|c|c|c|c|c|c|c|c|c|c|}
\hline Zone & Parameter & DON & NIV & FUS-X & 15-ADON & 3-ADON & DAS & HT-2 & $\mathrm{T}-2$ & T-2 + HT-2 \\
\hline \multirow{5}{*}{$\begin{array}{l}\text { Tudela } \\
(\mathrm{n}=10)\end{array}$} & $\%$ positive samples & 100.0 & 50.0 & 10.0 & 80.0 & 60.0 & 20.0 & 10.0 & 10.0 & 10.0 \\
\hline & $\begin{array}{l}\text { Mean value of positive } \\
\text { samples }\left(\mu \mathrm{g} \mathrm{kg}^{-1}\right)\end{array}$ & 296.2 & 25.0 & 3.6 & 26.1 & 9.1 & 1.2 & 14.7 & 10.0 & 24.8 \\
\hline & Mean value $\left(\mu \mathrm{g} \mathrm{kg}^{-1}\right)$ & 296.2 & 12.8 & 0.9 & 20.9 & 5.6 & 0.4 & 2.0 & 1.2 & 3.1 \\
\hline & Median value $\left(\mu \mathrm{g} \mathrm{kg}^{-1}\right)$ & 46.5 & 10.2 & 0.6 & 2.0 & 2.2 & 0.3 & 0.6 & 0.2 & 0.7 \\
\hline & $\begin{array}{l}\text { Maximum level found } \\
\qquad\left(\mu \mathrm{g} \mathrm{kg}^{-1}\right)\end{array}$ & 1111.3 & 38.9 & 3.6 & 64.8 & 20.1 & 1.7 & 14.7 & 10.0 & 24.8 \\
\hline \multirow{5}{*}{$\begin{array}{l}\text { Ribera Alta } \\
\quad(\mathrm{n}=16)\end{array}$} & $\%$ positive samples & 100.0 & 37.5 & 0.0 & 75.0 & 37.5 & 31.3 & 12.5 & 12.5 & 12.5 \\
\hline & $\begin{array}{l}\text { Mean value of positive } \\
\text { samples }\left(\mu \mathrm{g} \mathrm{kg}^{-1}\right)\end{array}$ & 72.5 & 14.7 & 0.6 & 6.4 & 3.1 & 1.1 & 15.3 & 7.1 & 22.4 \\
\hline & Mean value $\left(\mu \mathrm{g} \mathrm{kg}^{-1}\right)$ & 72.5 & 5.9 & 0.6 & 4.9 & 1.4 & 0.5 & 2.4 & 1.0 & 3.5 \\
\hline & Median value $\left(\mu \mathrm{g} \mathrm{kg}^{-1}\right)$ & 22.1 & 0.7 & 0.6 & 2.8 & 0.3 & 0.3 & 0.6 & 0.2 & 0.7 \\
\hline & $\begin{array}{l}\text { Maximum level found } \\
\qquad\left(\mu \mathrm{g} \mathrm{kg}^{-1}\right)\end{array}$ & 633.8 & 41.8 & $<$ LOD $^{*}$ & 37.3 & 11.4 & 1.5 & 23.5 & 8.3 & 31.8 \\
\hline \multirow{5}{*}{$\begin{array}{c}\text { Navarra } \\
\text { Media } \\
(\mathrm{n}=27)\end{array}$} & $\%$ positive samples & 100.0 & 23.1 & 0.0 & 76.9 & 26.9 & 46.2 & 23.1 & 3.8 & 23.1 \\
\hline & $\begin{array}{l}\text { Mean value of positive } \\
\text { samples }\left(\mu \mathrm{g} \mathrm{kg}^{-1}\right)\end{array}$ & 35.8 & 41.3 & 0.6 & 2.9 & 1.3 & 0.8 & 7.9 & 6.2 & 9.7 \\
\hline & Mean value $\left(\mu \mathrm{g} \mathrm{kg}^{-1}\right)$ & 35.8 & 9.7 & 0.6 & 2.3 & 0.6 & 0.5 & 2.5 & 0.6 & 3.1 \\
\hline & Median value $\left(\mu \mathrm{g} \mathrm{kg}^{-1}\right)$ & 27.9 & 0.7 & 0.6 & 2.3 & 0.3 & 0.3 & 0.6 & 0.2 & 0.7 \\
\hline & $\begin{array}{l}\text { Maximum level found } \\
\qquad\left(\mu \mathrm{g} \mathrm{kg}^{-1}\right)\end{array}$ & 85.7 & 142.5 & $<\mathrm{LOD}^{*}$ & 5.2 & 2.5 & 1.4 & 35.7 & 6.7 & 41.4 \\
\hline \multirow{5}{*}{$\begin{array}{c}\text { Tierra } \\
\text { Estella } \\
(\mathrm{n}=12)\end{array}$} & $\%$ positive samples & 100.0 & 25.0 & 0.0 & 100.0 & 25.0 & 75.0 & 75.0 & 16.7 & 75.0 \\
\hline & $\begin{array}{l}\text { Mean value of positive } \\
\text { samples }\left(\mu \mathrm{g} \mathrm{kg}^{-1}\right)\end{array}$ & 45.3 & 4.3 & 0.6 & 3.3 & 1.2 & 0.8 & 27.9 & 168.0 & 65.2 \\
\hline & Mean value $\left(\mu \mathrm{g} \mathrm{kg}^{-1}\right)$ & 45.3 & 1.6 & 0.6 & 3.3 & 0.5 & 0.7 & 21.1 & 28.1 & 49.2 \\
\hline & Median value $\left(\mu \mathrm{g} \mathrm{kg}^{-1}\right)$ & 36.9 & 0.7 & 0.6 & 3.0 & 0.3 & 0.7 & 4.4 & 0.2 & 4.6 \\
\hline & $\begin{array}{l}\text { Maximum level found } \\
\qquad\left(\mu \mathrm{g} \mathrm{kg}^{-1}\right)\end{array}$ & 119.6 & 5.5 & $<$ LOD* $^{*}$ & 6.8 & 1.5 & 1.1 & 200.5 & 332.0 & 532.5 \\
\hline \multirow{2}{*}{$\begin{array}{l}\text { Kruskal- } \\
\text { Wallis Test }\end{array}$} & Statistic & $1.902^{* *}$ & 3.884 & --- & $3.667 * *$ & $3.639 * *$ & 5.397 & 15.425 & 0.830 & --- \\
\hline & Significance & 0.593 & 0.274 & --- & 0.300 & 0.321 & 0.145 & 0.001 & 0.842 & --- \\
\hline \multirow{2}{*}{$\begin{array}{l}\text { Contingency } \\
\text { Test }\end{array}$} & Statistic & --- & 3.191 & 4.188 & 3.711 & 3.476 & 8.092 & 14.271 & 1.273 & --- \\
\hline & Significance & --- & 0.367 & 0.154 & 0.308 & 0.324 & 0.043 & 0.002 & 0.847 & --- \\
\hline
\end{tabular}

* Below the limit of detection; ** Median Test. 
Table 4. Summary of mycotoxin levels found in barley samples according to the variety of the crop.

\begin{tabular}{|c|c|c|c|c|c|c|c|c|c|c|}
\hline Variety & Parameter & DON & NIV & FUS-X & $15-\mathrm{ADON}$ & 3-ADON & DAS & HT-2 & $\mathrm{T}-2$ & $\mathrm{~T}-2+\mathrm{HT}-2$ \\
\hline \multirow{5}{*}{$\begin{array}{l}\text { Hispanic } \\
(\mathrm{n}=20)\end{array}$} & $\%$ positive samples & 100.0 & 5.0 & 0.0 & 40.0 & 15.0 & 5.0 & 0.0 & 0.0 & 0.0 \\
\hline & $\begin{array}{l}\text { Mean value of positive } \\
\text { samples }\left(\mu \mathrm{g} \mathrm{kg}^{-1}\right)\end{array}$ & 20.5 & 8.4 & 0.6 & 2.6 & 1.9 & 1.5 & 0.6 & 0.2 & 0.7 \\
\hline & Mean value $\left(\mu \mathrm{g} \mathrm{kg}^{-1}\right)$ & 20.5 & 1.1 & 0.6 & 1.1 & 0.6 & 0.3 & 0.6 & 0.2 & 0.7 \\
\hline & Median value $\left(\mu \mathrm{g} \mathrm{kg}^{-1}\right)$ & 16.7 & 0.7 & 0.6 & 0.2 & 0.3 & 0.3 & 0.6 & 0.2 & 0.7 \\
\hline & $\begin{array}{l}\text { Maximum level found } \\
\qquad\left(\mu \mathrm{g} \mathrm{kg}^{-1}\right)\end{array}$ & 67.0 & 8.4 & $<\mathrm{LOD}^{*}$ & 3.3 & 3.7 & 1.5 & $<\mathrm{LOD}^{*}$ & $<$ LOD $^{*}$ & $<$ LOD $^{*}$ \\
\hline \multirow{5}{*}{$\begin{array}{l}\text { Pewter } \\
(n=37)\end{array}$} & $\%$ positive samples & 97.3 & 37.8 & 2.7 & 67.6 & 40.5 & 62.2 & 56.8 & 21.6 & 56.8 \\
\hline & $\begin{array}{l}\text { Mean value of positive } \\
\text { samples }\left(\mu \mathrm{g} \mathrm{kg}^{-1}\right)\end{array}$ & 87.0 & 13.8 & 3.6 & 8.5 & 3.4 & 0.9 & 17.9 & 49.3 & 36.7 \\
\hline & Mean value $\left(\mu \mathrm{g} \mathrm{kg}^{-1}\right)$ & 84.7 & 5.6 & 0.7 & 5.8 & 1.6 & 0.6 & 10.4 & 10.8 & 21.2 \\
\hline & Median value $\left(\mu \mathrm{g} \mathrm{kg}^{-1}\right)$ & 36.8 & 0.7 & 0.6 & 2.8 & 0.3 & 0.7 & 1.6 & 0.2 & 2.0 \\
\hline & $\begin{array}{l}\text { Maximum level found } \\
\qquad\left(\mu \mathrm{g} \mathrm{kg}^{-1}\right)\end{array}$ & 937.2 & 41.8 & 3.6 & 64.6 & 20.1 & 1.4 & 200.5 & 332.0 & 532.5 \\
\hline \multirow{5}{*}{$\begin{array}{l}\text { Naturel } \\
(\mathrm{n}=15)\end{array}$} & $\%$ positive samples & 93.3 & 0.0 & 0.0 & 80.0 & 26.7 & 0.0 & 13.3 & 6.7 & 13.3 \\
\hline & $\begin{array}{l}\text { Mean value of positive } \\
\text { samples }\left(\mu \mathrm{g} \mathrm{kg}^{-1}\right)\end{array}$ & 37.2 & 0.7 & 0.6 & 2.3 & 1.4 & 0.3 & 3.3 & 4.7 & 5.6 \\
\hline & Mean value $\left(\mu \mathrm{g} \mathrm{kg}^{-1}\right)$ & 34.9 & 0.7 & 0.6 & 2.0 & 0.6 & 0.3 & 0.9 & 0.5 & 1.4 \\
\hline & Median value $\left(\mu \mathrm{g} \mathrm{kg}^{-1}\right)$ & 26.6 & 0.7 & 0.6 & 2.2 & 0.3 & 0.3 & 0.6 & 0.2 & 0.7 \\
\hline & $\begin{array}{l}\text { Maximum level found } \\
\qquad\left(\mu \mathrm{g} \mathrm{kg}^{-1}\right)\end{array}$ & 114.3 & $<$ LOD $^{*}$ & $<\mathrm{LOD}^{*}$ & 3.7 & 1.8 & $<\mathrm{LOD}^{*}$ & 4.4 & 4.7 & 9.1 \\
\hline \multirow{2}{*}{$\begin{array}{c}\text { Kruskal- } \\
\text { Wallis Test }\end{array}$} & Statistic & 8.315 & $7.220 * *$ & --- & 7.965 & 4.025 & $17.402 * *$ & $150.000 * * *$ & $233.000 * * *$ & --- \\
\hline & Significance & 0.016 & 0.007 & --- & 0.019 & 0.134 & $<0.001$ & 0.005 & 0.173 & --- \\
\hline \multirow{2}{*}{$\begin{array}{c}\text { Contingency } \\
\text { Test }\end{array}$} & Statistic & 1.564 & 13.200 & 1.199 & 6.685 & 4.126 & 28.563 & 22.256 & 5.693 & --- \\
\hline & Significance & 0.450 & 0.001 & 1.000 & 0.034 & 0.138 & $<0.001$ & $<0.001$ & 0.042 & --- \\
\hline
\end{tabular}

* Below the limit of detection; ** Median Test; *** Mann-Whitney U Test. 
Table 5. Summary of mycotoxin levels found in traditional and organic barley samples.

\begin{tabular}{|c|c|c|c|c|c|c|c|c|c|c|}
\hline $\begin{array}{l}\text { Type of } \\
\text { farming }\end{array}$ & Parameter & DON & NIV & FUS-X & 15-ADON & 3-ADON & DAS & HT-2 & $\mathrm{T}-2$ & $\mathrm{~T}-2+\mathrm{HT}-2$ \\
\hline \multirow{5}{*}{$\begin{array}{l}\text { Traditional } \\
(\mathrm{n}=13)\end{array}$} & $\%$ positive samples & 100.0 & 30.8 & 7.7 & 69.2 & 53.8 & 15.4 & 7.7 & 7.7 & 7.7 \\
\hline & $\begin{array}{l}\text { Mean value of positive } \\
\text { samples }\left(\mu \mathrm{g} \mathrm{kg}^{-1}\right)\end{array}$ & 232.9 & 25.9 & 3.6 & 23.4 & 8.0 & 1.2 & 14.7 & 10.0 & 24.8 \\
\hline & Mean value $\left(\mu \mathrm{g} \mathrm{kg}^{-1}\right)$ & 232.9 & 8.4 & 0.8 & 16.3 & 4.4 & 0.4 & 1.7 & 0.9 & 2.6 \\
\hline & Median value $\left(\mu \mathrm{g} \mathrm{kg}^{-1}\right)$ & 25.9 & 0.7 & 0.6 & 2.0 & 0.9 & 0.3 & 0.6 & 0.2 & 0.7 \\
\hline & $\begin{array}{l}\text { Maximum level found } \\
\qquad\left(\mu \mathrm{g} \mathrm{kg}^{-1}\right)\end{array}$ & 1111.3 & 38.9 & 3.6 & 64.8 & 20.1 & 1.7 & 14.7 & 10.0 & 24.8 \\
\hline \multirow{5}{*}{$\begin{array}{l}\text { Organic } \\
(\mathrm{n}=11)\end{array}$} & $\%$ positive samples & 100.0 & 0.0 & 0.0 & 54.5 & 45.5 & 9.1 & 0.0 & 0.0 & 0.0 \\
\hline & $\begin{array}{l}\text { Mean value of positive } \\
\text { samples }\left(\mu \mathrm{g} \mathrm{kg}^{-1}\right)\end{array}$ & 31.7 & 0.7 & 0.6 & 2.5 & 3.0 & 0.5 & 0.6 & 0.2 & 0.7 \\
\hline & Mean value $\left(\mu \mathrm{g} \mathrm{kg}^{-1}\right)$ & 31.7 & 0.7 & 0.6 & 1.4 & 1.5 & 0.3 & 0.6 & 0.2 & 0.7 \\
\hline & Median value $\left(\mu \mathrm{g} \mathrm{kg}^{-1}\right)$ & 18.0 & 0.7 & 0.6 & 1.9 & 0.3 & 0.3 & 0.6 & 0.2 & 0.7 \\
\hline & $\begin{array}{l}\text { Maximum level found } \\
\qquad\left(\mu \mathrm{g} \mathrm{kg}^{-1}\right)\end{array}$ & 89.1 & $<\mathrm{LOD}^{*}$ & $<\mathrm{LOD}^{*}$ & 3.5 & 6.7 & 0.5 & $<\mathrm{LOD}^{*}$ & $<\mathrm{LOD}^{*}$ & $<\mathrm{LOD}^{*}$ \\
\hline \multirow{2}{*}{$\begin{array}{l}\text { Mann-Whitney } \\
\text { U Test }\end{array}$} & Statistic & 53.000 & --- & --- & 56.500 & 59.000 & 66.000 & --- & --- & --- \\
\hline & Significance & 0.303 & --- & --- & 0.392 & 0.494 & 0.776 & --- & --- & --- \\
\hline \multirow{2}{*}{$\begin{array}{l}\text { Contingency } \\
\text { Test }\end{array}$} & Statistic & --- & 2.148 & 0.883 & 0.101 & 0.168 & 0 & 0.883 & 0.883 & --- \\
\hline & Significance & --- & 0.143 & 1.000 & 0.751 & 0.682 & 1.000 & 1.000 & 1.000 & --- \\
\hline
\end{tabular}

Below the limit of detection. 